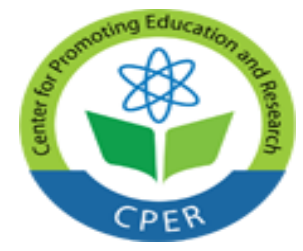

VOL: 1, ISSUE: 2

June/2019

https://ijssppnet.com/

E-ISSN: 2663-7200

(C) Center for Promoting Education and Research (CPER) USA

WWW.cpernet.org

\title{
EFFECT OF RETURN ON EQUITY (ROE), DEBT TO EQUITY RATIO (DER) AND EXCHANGE RATE ON STOCK PRICE PT. INDOFOOD SUKSES MAKMUR TBK
}

\author{
LC Anang Zamiarto \\ Student Master of Management \\ Universitas Krisnadwipayana Jakarta \\ PO BOX 774/Jat CM Jakarta 13077 Indonesia \\ Email: anangZ@gmail.com \\ Suharto \\ Associate Professor \\ Faculty of Economics \\ Universitas Krisnadwipayana Jakarta \\ PO BOX 774/Jat CM Jakarta 13077 Indonesia \\ Email:suharto@unkris.ac.id \\ Budhi Suparningsih \\ Lecturer \\ Faculty of Economics \\ Universitas Krisnadwipayana Jakarta \\ PO BOX 774/Jat CM Jakarta 13077 Indonesia \\ Email: budhiunkris@gmail.com
}

\section{Abstract}

This study aimed to determine the effect of return on equity (ROE), debt to equity ratio (DER), the exchange rate on stock prices either partially or simultaneously. Data were taken from 2008 to 2016. The data were analyzed using with regression.

The results showed that in partial return on equity (ROE), debt to equity ratio (DER) effect on stock prices and exchange rates partially no effect on stock prices. Variable return on return on equity (ROE), debt to equity ratio (DER) and the exchange rate simultaneously positive and significant effect on the stock price.

\section{Keywords: Return on Equity (ROE), Debt to Equity Ratio (DER), Exchange Rate, Stock Price Introduction}

In the current era of globalization, the development of Indonesia's economy experienced significant changes. Along with the economic development of the developing world work participate anyway and the more emerging companies, without exception, companies that have gone public. This causes each company has a goal to achieve as much profit as possible. Relative to the necessary financial management in calculating the company's operational results and analysis - financial analysis company that has been achieved within a certain time. In an effort to raise funds for the company's operations that go public may be obtained through the sale of shares to investors. Media that can be used by companies to sell their shares to the public is the capital market. The capital market is useful to bring together the parties those who require long-term funds with those who have the funds. Capital market activities are investment activities, namely investing activities either directly or indirectly with the hope in time the owners of capital to get some benefit from the capital investment results. For investors, the capital market they can choose the right investment objects with different rates of return and level of risk, while for the issuer through their capital markets to raise funds to support the long-term viability of their businesses. Namely investing activities either directly or indirectly with the hope in time the owners of capital to get some benefit from the capital investment 


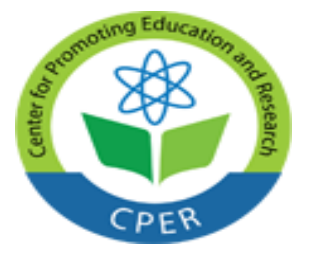

VOL: 1, ISSUE: 2

June/2019

https://ijssppnet.com/

E-ISSN: 2663-7200

\section{(C) Center for Promoting Education and Research (CPER) USA}

WWW.cpernet.org

results. For investors, the capital market they can choose the right investment objects with different rates of return and level of risk, while for the issuer through their capital markets to raise funds to support the long-term viability of their businesses. Namely investing activities either directly or indirectly with the hope in time the owners of capital to get some benefit from the capital investment results. For investors, the capital market they can choose the right investment objects with different rates of return and level of risk, while for the issuer through their capital markets to raise funds to support the long-term viability of their businesses.

It is appropriate every company must have financial statements that aim to provide information concerning the company's financial position, changes in financial position, and the company's operating activities that are useful for decision making. Capital will always spin in the short term to earn a profit from the activities of the organization. However, some parts of the capital that is available can be used to meet the obligations of the company to the creditors and investors. The financial statements show the company's financial position and performance of the company in profit. In the balance sheet to determine how much property or assets owned by companies that are on the side, we can see the assets and liabilities side to know where the funds contained in the assets.

Investors will be analyzing the report before making any investment. One way to do investor in the analysis is by analyzing the financial statements: balance sheet, statement of changes in capital and earnings reports and loss presented by the company in question in order to determine the condition and development of a company. To measure a company's financial position can be done by using financial ratios. Including return on equity (ROE), debt to equity ratio (DER), and the exchange rate USD. The ratio by investors can be used as a material for making rational decisions in investing.

Return on equity (ROE) is the rate of return generated by the company for each unit of currency as an asset of the company. In this sense, how big the company yields annually per one currency for investors invested in the company.

Debt to equity ratio (DER) is a ratio that compares the amount of debt to equity. This ratio is often used by analysts and investors to see how much debt the company when compared to equity held by the company or its shareholders. The higher the number DER then assumed the company has a higher risk on the liquidity of the company.

The exchange rate is the price of one unit of foreign currency in the domestic currency. In other words, the exchange rate is the price of the currency is exchanged for other currencies. The exchange rate is often used is the exchange rate on the dollar. Because the dollar is a relatively stable currency in the economy. Analysis of the financial statements is a thoughtful process in order to help evaluate the financial position and results of operations in the present and the past in order to determine the possible predictions about the condition and performance of the company in the future. Importance influence of return on equity (ROE), debt to equity ratio (DER), USD exchange rate and value of a company is to determine the company's financial condition is better than a years earlier, or even a loss. And investors can observe with evaluating financial performance and stock price projections. If the profits of the company are good, then the investor will not hesitate to buy shares of the company.

\section{Literature Review \\ Stock Price}

In investing in the capital market, especially the stock, the market price is an important concern for investors, in addition to the condition of the issuer and the state of its economy. The share price used in the transaction in the capital market is a price formed on the market mechanism of demand and supply that market. According to Rusdin (2008) share price, namely: "The share price is determined according to the law of demand-supply or bargaining power. More and more people want to buy, then the price of these shares tend to move up. Instead of more and more people who want to sell shares, the share price will move down". 


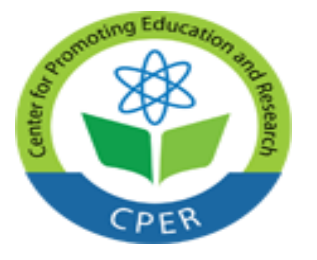

VOL: 1, ISSUE: 2

June/2019

https://ijssppnet.com/

E-ISSN: 2663-7200

\section{(C) Center for Promoting Education and Research (CPER) USA}

WWW.cpernet.org

Stocks are usually traded on the floor stock at the market price which will vary at each time, it will be related to the value of the stock. Briefly, Jogiyanto (2008) is that the value associated with that share book value, market value, and the value intrinsic. Jogiyanto (2008) explains: "Book value is the value of the issuer's shares according to the company's books. The market value is the value of shares on the stock market and the value intrinsic the actual value of the shares".

From the quote above, it was concluded that the stock price as well as commodity prices in a market economy the applicable law. Rise and fall of stock prices determined by the market in which the agreement on supply and demand. When there is a lot of demand, then the price offered is higher and when the demand decreases or less than the price offered will decrease or even lower.

\section{Return on Equity}

Return on equity is the ratio between the net profit after tax and total equity. Return on equity is a measure of income available to the owners of the company (both common shareholders and preferred shareholders) on the capital they have invested in the company (Syafri, 2008).

Return on equity is the ratio which shows the extent to which companies manage their own capital effectively, measure the level of profit from investments made their own capital owners or shareholders of the company (Sawir 2009). ROE shows the profitability of own capital or often called business profitability.

\section{Debt Equity Ratio}

Debt to equity ratio indicates how much money their own capital earmarked to pay debts (Halim, 2013: 56). Debt to equity ratio is useful to know the number of funds provided the borrower (creditors) with the owner of the company, in other words, this ratio to find every penny of equity capital used as collateral (Kashmir, 2010: 112). Thus, it can be concluded that the Debt to Equity Ratio shows how the company's ability to use existing capital to meet its obligations. The lower the ratio of Debt to Equity Ratio means the better the company's ability to pay longterm liabilities. The ratio of Debt to Equity Ratio is greater, the greater the ability of the company cannot pay its obligations.

By Marli (2010: 269), the higher the ratio of debt to equity ratio is means the greater the funds used as funding from outside sources. The greater the DER reflect the lower solvency of the company so that the company's ability to repay its debts is low, it means that the company's financial risk is relatively high. Companies that have a high risk of lead less interesting stock investment. The higher the leverage, measured by debt to equity ratio, the lower the PER of the company (Dennis, 2010: 114).

\section{Exchange Rate}

The exchange rate is the price of the currency of a country is measured in the currency of another country. The exchange rate is very important when deciding what to buy or purchase goods from abroad, because of the exchange rate we will translate the prices of goods from various countries into the currency of our country. The exchange rate also referred to as a comparison value in exchange of different currencies. So there is a comparison of values between the two currencies, and the comparison is called the exchange rate. If the price of foreign currency exchange rate or price rise in the country, it usually will cause the price of the imported goods to become more expensive if it has decreased the price of imported goods would normally cost. We often encounter different levels of the exchange rate for foreign currency, these differences arise because of things like the difference between the buying and selling rates. This difference is due to the average difference between the time of payment, the difference in the level of security in the receipt of payment. 


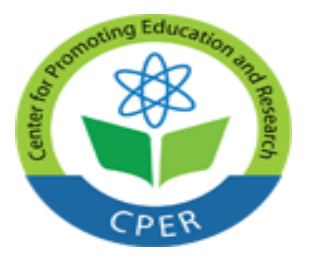

VOL: 1, ISSUE: 2

June/2019

https://ijssppnet.com/

E-ISSN: 2663-7200

\section{(C) Center for Promoting Education and Research (CPER) USA}

WWW.cpernet.org

The role of the exchange rate is needed in foreign exchange. Although this time the foreign exchange trading has been a lot of place in various financial centers spread across major cities in the world. As the development of technology, it has now become single market circuits that operate 24 hours a day. Categories are very important in foreign exchange trading is futures trading or forward trading and spot trading or spot trading. Futures trading is that several parties who agree to exchange currencies at a time when that will come based on the rate agreed upon. While spot trading a currency exchange directly.

\section{Research Methods}

\section{Research Design}

This research uses explanatory analysis approach, which aims for the relationship and influence between independent and dependent variables. Furthermore, the present invention will be described, by observation and research and describe the nature of the events ongoing at the time the research is done and examine the causes of the symptoms. In this study examines the effect of return on equity (ROE), debt to equity ratio (DER) and the USD exchange rate value to share price PT Indofood Sukses Makmur Tbk.

Design of this research model is simultaneous return on equity (ROE), debt to equity ratio (DER) and value exchange rate of USD on stock price PT. Indofood Sukses Makmur Tbk, as well as on the relationship of each independent variable debt to equity ratio (DER), return on equity (ROE), and value exchange on the dependent variable stock price at PT. Indofood Sukses Makmur Tbk.

\section{Population and Sample}

The population is a generalization region consisting of the object or subject of objects, people and events that have a certain quantity and characteristics defined by the researchers to learn and then drawn conclusions (Sugiyono, 2008). The samples are part of the characteristics possessed by the population. If a large population, the researchers can use the sample, the conclusion will be applied to the population. For that samples taken from the population to be truly representative or represent (Sugiyono, 2008).

The population of this research is financial data return on equity (ROE), debt to equity ratio (DER), value USD exchange rate and stock price PT. Indofood Sukses Makmur Tbk. The periodization study population includes sample data unit of occurrence data used in 2008 the year 2016. Noting the data return on equity (ROE), debt to equity ratio (DER), value USD exchange rate and stock prices, which on the common fluctuations in the data up and down, then the data is considered representative sample is the year of 2008-2016.

\section{Techniques of Data Collection}

The technique used to collect the data and materials required are of secondary data, meaning that the data obtained indirectly from the object of research. In this case, the secondary data obtained from library research is the method of data collection is done to obtain the theory related to the problem under study, where this theory can be used as a basis for examining the issues discussed. This is done by reading, studying and analyzing the literature books, paper articles, and other resources in order to obtain the theoretical knowledge about the problems that research. The process the data in this study is the classical assumption (BLUE) with regression.

\section{Results and Discussion}

\section{A. Research Result}

There are three variables proposed, could affect the stock price is return on equity (ROE), debt to equity ratio (DER), and value exchange rate. The description is a description of each variable at PT Indofood Sukses Makmur Tbk is the result of multiple regression analysis, testing and coping with its assumptions, hypothesis testing and further elaborate on the interpretation of the effect of several independent variables on the dependent variable. 


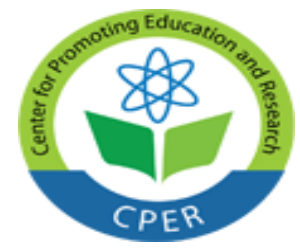

VOL: 1, ISSUE: 2

June/2019

https://ijssppnet.com/

E-ISSN: 2663-7200

(C) Center for Promoting Education and Research (CPER) USA

WWW.cpernet.org

\section{Debt to Equity Ratio (DER)}

From the research that the debt-to-equity (DER) is the ratio between the total debt (current liabilities and long term liabilities) and capital indicates the company's ability to meet its obligations by using existing capital. Based on the data obtained, the development of debt to equity ratio (DER) for the period from 2008 to 2016 per quarter. 2.

\section{Return On Equity (ROE)}

From the research that return on equity (ROE) is the ratio which shows the extent to which the company manages its own capital (net worth) effectively, measure the level of profit from investments that have done their own capital owners or shareholders of the company (Sawir 2009). Based on the data obtained, development return on equity (ROE) for the period from 2008 to 2016 per quarter.

\section{Exchange Rate}

From the research that the exchange rate is the price of the currency of a country is measured in the currency of another country. The exchange rate also referred to as a comparison value in exchange of different currencies. Based on the data obtained, the exchange rate development of the US dollar (USD) for the period from 2008 to 2016 per quarter.

\section{Stock Price}

From the research that the independent variable is the stock price. The share price used is the closing stock price. The price of a stock is essentially determined by forces of supply and demand for the stock in question is itself a reflection of investors' expectations of the performance of stocks in the future. The size of the stock price is based on research Lev and Zarowin (1999), Triyono and Jogiyanto (2000). In this study, the share price used is the closing stock price on the date of the announcement of the financial statements, which is transformed into the number of $t-5$, $\mathrm{t}-4, \mathrm{t}-3, \mathrm{t}-2, \mathrm{t}-1, \mathrm{t} 0, \mathrm{t}+1, \mathrm{t}+2, \mathrm{t}+3, \mathrm{t}+4 \mathrm{t}+5$. Determination window period 5 days and 5 days after to avoid any confounding effect. Based on data obtained stock price developments, for the period from 2008 to 2016 per quarter.

\section{B. Discussion}

After the calculation of the data set, the results of research on the influence of the independent variables like, return on equity (ROE) (X1), debt to equity ratio (DER) (X2), value exchange rate (X3), the dependent variable is the stock price (Y).

\section{stock price}

1.Effect of simultaneous return on equity (ROE), debt to equity ratio (DER), and value exchange rate on

The results of data processing using SPSS 17 prove, that turned out to be a synergy variable return on equity (ROE), debt to equity (DER) and value exchange simultaneously able to contribute a relatively quite strong, and positive impact on stock prices.

Based on test results obtained statistical calculation results obtained regression equation regression coefficient that is equal to $\mathrm{Y}=15.795+0.670(\mathrm{X} 1)+0.307(\mathrm{X} 2)+0.553(\mathrm{X} 3)$. Based on the multiple regression equation (simultaneous) can be seen toward relationships resulting from the independent variable on the dependent variable, assuming other variables constant, namely:

1.X1 variable regression coefficient is positive indicates a positive relationship of variable return on equity (ROE), which led to a significant increase of 0,670 and 0.003 for prob sig (Significant for $\alpha=0.01$ ) in the stock price. 


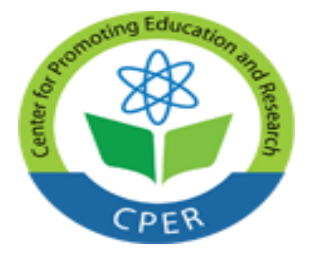

VOL: 1, ISSUE: 2

June/2019

https://ijssppnet.com/

E-ISSN: 2663-7200

\section{(C) Center for Promoting Education and Research (CPER) USA}

WWW.cpernet.org

2.The regression coefficient is positive X2 shows the relationship of variable debt to equity (DER), which led to a significant increase of 0,307 and 0.000 for prob sig (Significant for $\alpha=0.01$ ) in the stock price.

3. The regression coefficient is positive $\mathrm{X} 3$ showed a positive correlation of variables value exchange is causing a significant increase of 0,553 and 0.009 for prob sig (Significant for $\alpha=0.01$ ) in the stock price.

Through this estimate can be drawn, that the return on equity (ROE) gives an indication of the influence of the relatively higher than the debt to equity ratio (DER) and value exchange rate. The simultaneous effect predicted to probe constant was positive amounting to 15.785 with sig probability $(0.000)$ or significant to $\alpha 0.01$, respectively. This means that simultaneously the three predictor variables that provide linear volatile impact on stock prices, but still within the tolerances significantly $(\alpha<0: 10 \%)$.

The results showed that the return on equity (ROE) have a positive influence on stock prices and return on equity (ROE) has the most dominant influence of the other variables that debt to equity ratio (DER) and the value in the exchange rate affect the stock price. This suggests that the return on equity (ROE) is the most decisive factor increase in the share price compared with the debt to equity (DER) and the exchange rate.

More can be explained, that simultaneously the three variables were able to predict the effect of a positive and significant for $\alpha$ 0:01, and were able to make a contribution that is strong enough to change linearly with stock prices, $\mathrm{R}$-Square $=0,554$ and the estimated residual explained residual or at 10.63592). This condition is also able to explain the return on equity (ROE), debt to equity ratio (DER) and the exchange rate simultaneously giving effect to the share price which in this case can be explained by the effect of $55.4 \%$ and the balance, or by $44.6 \%$ is as estimated residual unexplained residual influenced by other variables outside the model, which is outside the variable return on equity (ROE), debt to equity ratio (DER) and value exchange.

\section{Effect of partial return on equity (ROE) on stock price}

If simultaneously variable return on equity (ROE) was able to synergize with other variables that can affect the level of stock prices, it is an interesting thing to be studied more in depth is how when viewed partially, if the variable return on equity (ROE) is also capable of affecting high or low the stock price.

Of partial regression equation above can be seen toward relationships resulting from the independent variable on the dependent variable, assuming other variables constant, namely: $\hat{\mathrm{Y}}=15.795+0.670\left(\mathrm{X}_{1}\right)+\mathrm{e}$.

The regression coefficient variable positive sign indicates a positive relationship of variable return on equity (ROE), which led to an increase of 0,670 and significant for the prob sig 0.003 (Significant for the stock price. And in order to examine the relationship in partial return on equity (ROE) to stock prices significantly or not, testing significant $=0.003$ for. Based on the above calculation can be stated that significant $t$ value $=0.003$ for, it means there is no significant influence return on equity (ROE) on stock prices. $\left.\mathrm{X}_{1} \alpha=0.01\right) \alpha=0.01 \alpha=0.01$

The results showed that the return on equity (ROE) has a positive and significant effect on stock prices. More can be explained, that in partial return on equity (ROE) were able to predict the effect of a positive and significant (Note Prob Sig. 0.003), and is able to make a contribution that is strong enough to share price, (R-Square $=0.510$ with residual explained residual estimation or for 5979). This condition is also able to explain the return on equity (ROE) is partially influenced by the effect on stock prices by $51 \%$. More details, the partial effect level return on equity (ROE). $\alpha 0.01$ 


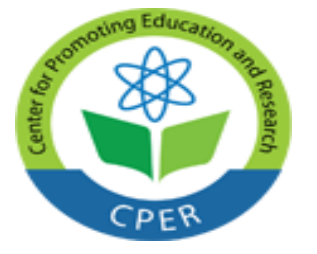

VOL: 1, ISSUE: 2

June/2019

https://ijssppnet.com/

E-ISSN: 2663-7200

(C) Center for Promoting Education and Research (CPER) USA

WWW.cpernet.org

\section{Effect of partial debt to equity ratio (DER) on stock price}

If the simultaneously variable debt to equity ratio (DER) is able to synergize with other variables, but an interesting thing to be studied more in depth is how when viewed partially, if the variable debt to equity ratio (DER) may also affect the high or low stock price. Of partial regression equation above can be seen toward relationships resulting from the independent variable on the dependent variable, assuming other variables constant, namely: $\hat{Y}=$ $15.795+0.307\left(\mathrm{X}_{2}\right)+\mathrm{e}$

The variable regression coefficient is positive, which indicates a positive relationship of variable debt to Equity Ratio (DER), which causes an increase of by 0,307 and significant to t prob sig 0.000 (Significant for) the stock price. And to examine the relationship in partial debt to equity ratio (DER) on stock prices significantly or not, then be tested with significant $t 0.000$. Based on the calculation above can be stated that significant $t$ value $=0.000$ for, it means there is a partial effect debt to equity ratio (DER) on stock prices $\mathrm{X}_{2} \alpha 0.01 \alpha=0.01 \alpha=0.01$

The results showed that the debt to equity ratio (DER) has a positive effect on stock prices. More can be explained, that partially debt to equity ratio (DER) is able to influence positive and significant for (note t Prob Sig. 0.000), and is able to make a contribution that is strong enough to share price, (R-Square $=0.551$ with the estimated residual explained residual or at 11.33660). This condition is also able to explain the debt to equity ratio (DER) partially giving effect to the share price of $55.1 \% . \alpha 0.01$

\section{Effect of exchange rate value on stock price}

If the exchange rate value variables simultaneously able to synergize with other variables that are quite capable of affecting the level of stock prices, it is an interesting thing to be studied more in depth is how when viewed partially, if the variable value is also able to influence the exchange rate higher or lower stock prices. Of partial regression equation above can be seen toward relationships resulting from the independent variable on the dependent variable, assuming other variables constant, namely: $\hat{\mathrm{Y}}=15.795+0.553\left(\mathrm{X}_{3}\right)+\mathrm{e}$

The regression coefficient variable positive sign indicates a positive relationship of variable Value Exchange is causing an increase of 0.553 and exhibited significantly to prob sig 0.009 (Significant for the stock price. And in order to examine the relationship in partial value exchange rate against the stock price significantly or not, testing significant $\mathrm{t}=0.009$ for. Based on the calculation above can be stated that significant $\mathrm{t}$ value $=0.009$ for, it means there is a significant effect of exchange rates on stock prices. $\left.\mathrm{X}_{3} \alpha 0.01\right) \alpha=0.01 \alpha=0.01$

The results showed that the exchange rate does not have a positive and significant effect on stock prices. More can be explained, that in the partial exchange rate is not able to predict the effect of a positive and significant for (note prob sig. 0.009), and was not able to make a contribution to the stock price, (r-square $=0.034$ and the estimated residual explained residual or at 24.79495). This condition is also able to explain the value of the partial exchange rate does not give effect to the stock price effect of $3.4 \% . \alpha 0.01$

\section{Conclusions and Recommendations \\ Conclusion}

In research return on equity (ROE), debt to equity ratio (DER) and the exchange rate on the stock price on PT. Indofood Sukses Makmur, Tbk period 2008 to 2016, it can be concluded as follows:

1.Return on equity (ROE) is the ratio which shows the extent to which the company manages its own capital (net worth) as effectively or measure the level of profit from investments made their own capital owners or shareholders of the company. 


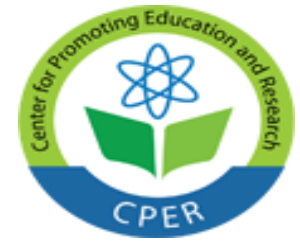

VOL: 1, ISSUE: 2

June/2019

https://ijssppnet.com/

E-ISSN: 2663-7200

(C) Center for Promoting Education and Research (CPER) USA

WWW.cpernet.org

a. Debt to equity ratio $(D E R)$ is the ratio between the total debt (current liabilities and long term liabilities) and capital indicates the company's ability to meet its obligations by using existing capital.

$b$. Exchange rate value is the price of the currency of a country is measured in the currency of another country. The exchange rate as well as a comparison of the value in different currency exchange.

c. The market price is the price of a stock which is essentially determined by forces of supply and demand for the stock in question which is a reflection of investors' expectations of the performance of stocks in the future.

2.Partially return on equity (ROE) influence the stock price by the acquisition of $r$-square $=0.510$ and the estimated residual explained residual or for 5.979). This condition is also able to explain the return on equity (ROE) is partially influenced by the effect on stock prices by $51 \%$.

3.Partially debt to equity ratio (DER) influences the stock price by the acquisition of $r$-square $=0551$ and the estimated residual explained residual or at 11.33660). This condition is also able to explain the debt to equity ratio (DER) partially giving effect to the stock price effect of $55.1 \%$.

4.Partially value exchange does not influence the stock price with the acquisition (r-square $=0.034$ with estimates that explained residual or at 24.79495). This condition is also described that the partial exchange rate does not give effect to the stock price effect of $3.4 \%$.

5.Simultaneously, return on equity (ROE), debt to equity ratio (DER) and the exchange rate and a significant positive effect on the stock price. This is indicated by the acquisition of R-square $=0.554$ with estimates that explained residual or at 10.63592). This condition is also able to explain the debt to equity ratio (DER), return on equity (ROE) and value exchange simultaneously influenced by $55.4 \%$, and the remainder or $44.6 \%$ is a residual estimate that the residual unexplained influenced by other variables outside the model.

\section{Recommendations}

1. Investors can improve the understanding of the interaction of variables associated with capital market instruments, but an understanding of the variables that come from outside the company partially (the exchange rate) cannot be fully taken into account as described in this study.

2. The higher return on equity (ROE) showed the better the company's ability to capitalize on the investments made by the company. The advantage to giving effect to the stock price and ultimately increase the stock price.

\section{References}

Dennis Ariefianto. 2010. Analisis Pengaruh Variance of Earnings Growth (VEG), Net Profit Margin, dan Debt to Equity Ratio on Price Earning Ratio (PER) (Studi Empiris pada Perusahaan Sektor Properti Tahun 20052008). Skripsi. Universitas Islam Negeri Syarif Hidayatullah.

Halim. 2013. Akuntansi Keuangan Daerah. Salemba Empat: Jakarta.

Jogiyanto. 2008. Teori Portofolio dan Analisis Investasi. Yogayakarta : BPFE.

Kasmir. 2010. Manajemen Perbankan. Jakarta: Rajawali Pers.

Lev, B., dan P. Zarowin. 1999. "The Boundaries of Financial Reporting and How to Extend Them". Journal of Accounting Research, Vol. 37, No. 2, hal. 353-385. 
